\title{
Evaluating the Serum Transforming Growth Factor-Beta 1 Level in Chronic Kidney Disease Caused by Glomerulonephritis
}

\author{
Tuan Van Nguyen ${ }^{1}$, Ky Duc Ngo ${ }^{2}$, Minh Hoang Thi ${ }^{3}$, Lan Thi Phuong Dam (iD $^{3}$ and Thuan Quang \\ Huynh (iD ${ }^{3, *}$ \\ ${ }^{1}$ Vinh Medical University, Vinh, Vietnam \\ ${ }^{2}$ Nghe An Friendship General Hospital, Vinh, Vietnam \\ ${ }^{3}$ Biochemistry Department, 103 Military Hospital, Vietnamese Military Medical University, Hanoi, Vietnam \\ "Corresponding author: Biochemistry Department, 103 Military Hospital, Vietnamese Military Medical University, Hanoi, Vietnam. Postal Code: 10000, Email: \\ huynhquangthuan2002@yahoo.com
}

Received 2021 January 22; Accepted 2021 March 02.

\begin{abstract}
Background: The transforming growth factor-beta 1(TGF- $\beta 1$ ) has been demonstrated as one of the main factors in the progression of fibrosis and sclerosis glomerular damages. Glomerulonephritis is one common cause of chronic kidney disease (CKD) with the promotion of inflammatory renal damage containing fibrosis and sclerosis glomerular.

Objectives: This study aimed to evaluate the TGF- $\beta 1$ level in CKD patients and compare it with the healthy control group.

Methods: This cross-sectional case-control study was carried out on 212 subjects admitted to the Nghe An Friendship General Hospital in Vietnam from March 2018 to February 2020. The case group included 152 patients diagnosed with CKD caused by glomerulonephritis, and the control group included 60 healthy individuals. The TGF- $\beta 1$ was determined in serum by ELISA method.

Results: The serum TGF- $\beta 1$ concentration of the healthy control group and CKD group was $13.45 \pm 7.17$ and $32.35 \pm 11.74$, respectively. The CKD group had a significantly higher TGF- $\beta 1$ level than the control group $(\mathrm{P}<0.05)$. The CKD group with the eGRP $\geq 60$ $\mathrm{mL} / \mathrm{min} / 1.73 \mathrm{~m}^{2}$ group had a higher TGF- $\beta 1$ level than the eGRP $<60 \mathrm{~mL} / \mathrm{min} / 1.73 \mathrm{~m}^{2}$ group, and the TGF- $\beta 1$ level increased from stage 1 to stage $5(\mathrm{P}<0.001)$. The TGF- $\beta 1$ had a medium correlation to urea, creatinine, and hs-CRP.

Conclusions: The concentration of TGF- $\beta 1$ in the CKD group was higher than the control group so that it increased early from the first stage of the disease.
\end{abstract}

Keywords: Inflammatory, Fibrosis, Sclerosis, Glomerular

\section{Background}

The transforming growth factor-beta 1 (TGF- $\beta 1$ ) is essential for normal development, repair of the organization, and maintenance of the organ function. However, an increase in the concentration of TGF- $\beta 1$ causes pathological changes in chronic kidney disease (CKD). In human glomerulonephritis, such as focal segmental glomerulosclerosis (FSGS), IgA glomerulonephritis, sickle-shaped glomerulonephritis, lupus glomerulonephritis, and diabetic nephropathy, TGF- $\beta 1$ plays an important role in contributing glomerular sclerosis (1-4). The main feature of these pathologies is the excessive accumulation of extracellular material and the increased effect of TGF- $\beta 1$ in the glomerulus and interstitial nephropathy. In the glomerulus, TGF- $\beta 1$ contributes mainly to the transformation of the glomerular membrane, fibrosis, and glomerular sclerosis. In the renal tubules, TGF- $\beta 1$ is involved both directly and indirectly in tubular degeneration (5). Several studies have demonstrated the increase of TGF- $\beta 1$ in CKD patients $(6,7)$, leading to a new therapy in the prevention and treatment of CKD (8). This study aimed to evaluate the serum level of TGF- $\beta 1$ in CKD patients and the related changes during other stages of the disease.

\section{Objectives}

This study aimed to evaluate the TGF- $\beta 1$ level in CKD patients and compare it with the healthy control group.

\section{Methods}

This cross-sectional case-control study was carried out on 212 subjects admitted to the Nghe An Friendship General Hospital in Vietnam from March 2018 to February 2020. The case group included 152 patients diagnosed with CKD caused by glomerulonephritis, and the control group 
included 60 healthy individuals. The case group was divided into two small groups based on eGFR value (the CKD group with the eGRP $\geq 60 \mathrm{~mL} / \mathrm{min} / 1.73 \mathrm{~m}^{2}$ and the CKD group with eGRP $<60 \mathrm{~mL} / \mathrm{min} / 1.73 \mathrm{~m}^{2}$ ).

The inclusion criteria were: age $\geq 18$; having one of the following symptoms: (1) markers of kidney damage such as albuminuria (ACR $\geq 30 \mathrm{mg} / \mathrm{g}$ ), or urine sediment abnormalities, or electrolyte and others abnormalities in tubular disorders, or abnormalities detected in histology, or structural abnormalities detected in imaging, or edema, or hypertension; and (2) decreased estimated glomerular filtration rate $(\mathrm{eGFR})<60 \mathrm{~mL} / \mathrm{min} / 1.73 \mathrm{~m}^{2}$ presented for more than three months (KDIGO 2012).

Exclusion criteria were: (1) pregnancy; (2) transplantation;(3) diabetes mellitus (DM); (4) hypertension (HTN);(5) CKD caused by HTN or DM; (6) acute period of chronic kidney failure; (7) acute kidney failure; (8) patients who had heart diseases before CKD; (9) patients who had a fever during sampling phase; and (10) patients using statin, corticoid, and the drugs which increased creatinine clearance such as cimetidine, trimethoprim. The inclusion criteria for the subjects in the control group were: (1) age $\geq 18$; (2) no history of kidney damage, HTN, and DM; (3) normal kidney function and structure; and (4) eGRP $>60 \mathrm{~mL} / \mathrm{min} / 1.73$ $\mathrm{m}^{2}$.

\subsection{Samples}

The plasma of all subjects were collected to determine the concentration of urea and creatinine in the AU system (Beckman Coulter). The serum was used to qualify TGF$\beta 1$. The EDTA blood was collected to determine red blood cells, hematocrit, and hemoglobin. The clinical characteristics such as height, weight, body mass index (BMI), and waist circumference were also collected. The eGFR was calculated by using the CKD-EPI creatinine equation 2009, recommended by the National Kidney Foundation (NKF).

In the equation, the unit of eGFR (estimated glomerular filtration rate) was $\mathrm{mL} / \mathrm{min} / 1.73 \mathrm{~m}^{2}$; the unit of $\mathrm{SCr}$ (standardized serum creatinine) was $\mathrm{mg} / \mathrm{dL} ; \kappa=0.7$ (females) or 0.9 (males); $\alpha=-0.329$ (females) or -0.411 (males); min, the minimum of $\mathrm{SCr} / \kappa$ or 1 ; max, the maximum of $\mathrm{SCr} / \kappa$ or 1 ; age, years.

TGF- $\beta 1$ was concentrated by double-antibody sandwich enzyme-linked immunosorbent assay (ELISA) with the reagent of DRG manufacturer (American, EIA-1864) in the Evolis Twin Plus automation machine (American). BMI was calculated as the ratio of the weight to the height $\left(\mathrm{kg} / \mathrm{m}^{2}\right)$.

\subsection{Statistical Analysis}

The data were analyzed by Excel 2013 and SPSS software version 18.0. The non-normal quantitative variables were presented as median and quartiles (25th and 75th). The quantitative variables with normal distribution were presented as mean \pm standard deviation, maximum, minimum. The difference between the means of the groups was calculated by the ANOVA test. The results were considered to be significant at $\mathrm{P}<0.05$.

\section{Results}

\subsection{Clinical Characteristic of the Subjects}

As Table 1 shows, there were no significant differences between the healthy control group, CKD with eGFR $\geq 60 \mathrm{~mL} / \mathrm{min} / 1.73 \mathrm{~m}^{2}$ group, and CKD with eGFR $<60$ $\mathrm{mL} / \mathrm{min} / 1.73 \mathrm{~m}^{2}$ group in age, gender, height, weight, waist circumference, and BMI. The RBC, hematocrit, and hemoglobin were significantly lower in healthy controls compared to CKD with eGFR $\geq 60 \mathrm{~mL} / \mathrm{min} / 1.73 \mathrm{~m}^{2}$ group and the CKD with eGFR $<60 \mathrm{~mL} / \mathrm{min} / 1.73 \mathrm{~m}^{2}$ group. The plasma urea and creatinine were significantly higher in healthy controls compared to CKD with eGFR $\geq 60$ $\mathrm{mL} / \mathrm{min} / 1.73 \mathrm{~m}^{2}$ group and the CKD with eGFR $<60$ $\mathrm{mL} / \mathrm{min} / 1.73 \mathrm{~m}^{2}$ group. The eGFR of CKD with eGFR $<60$ $\mathrm{mL} / \mathrm{min} / 1.73 \mathrm{~m}^{2}$ group was significantly lower than the two other groups (Table 1).

\subsection{The TGF- $\beta 1$ Levels}

The TGF- $\beta 1$ levels in the CKD group were higher than the control $(\mathrm{P}<0.001)$ (Table 2$)$. In CKD group, the eGFR $<60 \mathrm{~mL} / \mathrm{min} / 1.73 \mathrm{~m}^{2}$ had higher TGF- $\beta 1$ level than the eGFR $\geq 60 \mathrm{~mL} / \mathrm{min} / 1.73 \mathrm{~m}^{2}$ group $(\mathrm{P}<0.001$ ) (Table 3 ). The TGF$\beta 1$ level increased from stage 1 to 5 of $\mathrm{CKD}(\mathrm{P}<0.001)$ (Table 4).

\subsection{The Correlation Between TGF- $\beta 1$ Levels and Other Charac-} teristics

While the TGF- $\beta 1$ levels had a negative correlation with eGFR, hematocrit, red blood cell, and hemoglobin, it had a positive correlation with plasma urea, creatinine, and hsCRP (Table 5).

\section{Discussion}

The TGF- $\beta 1$ has been considered as one of the main cytokines in the pathogenesis of renal inflammation and fibrosis (9). Some pathogenic evidence showed that the inflammation progressed silently and almost unrecovered in the CKD even during the early stage (10). TGF- $\beta 1$ has been found to be increasing in CKD patients than in healthy individuals. Our results were similar to the reports of some other studies (11-15). Three main mechanisms increase the TGF- $\beta 1$ in serum. First, the subjects of this study were CKD patients caused by glomerulonephritis, and the patients with CKD caused by other chronic diseases such as 
$e G F R=141 \times \min \left(\frac{S C r}{\kappa}, 1\right) \alpha \times \max \left(\frac{S C r}{\kappa}, 1\right)-1.209 \times 0.993$ Age $\times 1.018($ if female $) \times 1.159($ if black $)$

\begin{tabular}{|c|c|c|c|c|}
\hline \multirow{2}{*}{ Variables } & \multirow{2}{*}{ Healthy Control Group } & \multicolumn{2}{|c|}{ Case Group } & \multirow{2}{*}{ P Value $^{\text {b }}$} \\
\hline & & eGFR $\geq 60 \mathrm{~mL} / \mathrm{min} / 1.73 \mathrm{~m}^{2}$ & eGFR $<60 \mathrm{~mL} / \mathrm{min} / 1.73 \mathrm{~m}^{2}$ & \\
\hline No. (\%) & $60(100)$ & $79(100)$ & $73(100)$ & \\
\hline Age & $47.07 \pm 17.44$ & $49.03 \pm 13.80$ & $51.26 \pm 16.32$ & $P_{\text {all }}>0.05$ \\
\hline Gender & & & & $\mathrm{P}_{\mathrm{all}}>0.05$ \\
\hline Male & $30(50)$ & $38(48.1)$ & $41(56.1)$ & \\
\hline Female & $30(50)$ & $22(51.9)$ & $51(43.9)$ & \\
\hline Height (m) & $1.61 \pm 0.08$ & $1.62 \pm 0.08$ & $1.59 \pm 0.08$ & $P_{\text {all }}>0.05$ \\
\hline Weight (kg) & $57.22 \pm 8.54$ & $56.28 \pm 8.58$ & $51.55 \pm 9.61$ & $P_{\text {all }}>0.05$ \\
\hline Waist (cm) & $75.37 \pm 6.47$ & $77.25 \pm 7.09$ & $77.50 \pm 7.10$ & $\mathrm{P}_{\mathrm{all}}>0.05$ \\
\hline $\operatorname{BMI}\left(\mathbf{k g} / \mathbf{m}^{2}\right)$ & $21.88 \pm 2.33$ & $21.54 \pm 2.74$ & $20.50 \pm 2.75$ & $P_{\text {all }}>0.05$ \\
\hline Red blood cell (T/L) & $4.76 \pm 0.44$ & $4.78 \pm 0.76$ & $3.60 \pm 1.01$ & $P_{1}>0.05 ; P_{2}<0.05 ; P_{3}<0.05$ \\
\hline Hematocrit (\%) & $40.57 \pm 4.08$ & $40.39 \pm 7.09$ & $29.84 \pm 9.21$ & $\mathrm{P}_{1}>0.05 ; \mathrm{P}_{2}<0.05 ; \mathrm{P}_{3}<0.05$ \\
\hline Hemoglobin $(g / L)$ & $133.85 \pm 14.26$ & $138.88 \pm 25.79$ & $102.72 \pm 31.49$ & $P_{1}>0.05 ; P_{2}<0.05 ; P_{3}<0.05$ \\
\hline Urea $(\mathbf{m m o l} / \mathrm{L})$ & $5.78 \pm 1.50$ & $7.13 \pm 7.99$ & $18.51 \pm 11.76$ & $\mathrm{P}_{\mathrm{all}}<0.05$ \\
\hline Creatinine $(\mu \mathrm{mol} / \mathbf{L})$ & $84.60 \pm 17.06$ & $83.20 \pm 22.27$ & $362.90 \pm 324.95$ & $\mathrm{P}_{\text {all }}<0.05$ \\
\hline eGFR (mL/min/1.73m²) & $84.54 \pm 19.58$ & $86.58 \pm 20.23$ & $24.34 \pm 15.94$ & $\mathrm{P}_{\text {all }}<0.05$ \\
\hline
\end{tabular}

a Values are expressed as mean \pm SD unless otherwise indicated.

${ }^{\mathrm{b}} \mathrm{P}_{\text {all }}$, compare within 3 groups healthy control group, CKD group with eGFR $>60 \mathrm{~mL} / \mathrm{min} / 1.73 \mathrm{~m}^{2}$, and CKD group with eGFR $>60 \mathrm{~mL} / \mathrm{min} / 1.73 \mathrm{~m}^{2} ; \mathrm{P}_{1}$, control group vs CKD group eGFR $\geq 60 \mathrm{ml} / \mathrm{min} / 1.73 \mathrm{~m}^{2} ; \mathrm{P}_{2}$, control group vs CKD group eGFR $<60 \mathrm{~mL} / \mathrm{min} / 1.73 \mathrm{~m}^{2}, \mathrm{P}_{3}$ : CKD group eGFR $\geq 60 \mathrm{~mL} / \mathrm{min} / 1.73 \mathrm{~m}^{2}$ vs CKD group eGFR, 60 $\mathrm{mL} / \mathrm{min} / 1.73 \mathrm{~m}^{2}$.

Table 2. The Concentration of TGF- $\beta 1$ in Control and Case Groups

\begin{tabular}{l|c|c|c|}
\hline TGF $\beta$ 1 $(\mathbf{n g} / \mathbf{m L})$ & Healthy Control Group $(\mathbf{n}=\mathbf{6 0})$ & Case Group $(\mathbf{n}=\mathbf{1 5 2})$ & P Value \\
\hline $\bar{X} \pm$ SD & $13.45 \pm 7.17$ & $32.35 \pm 11.74$ & $<0.001$ \\
\hline Median (25th; 75th) & $12.44(8.28 ; 17.59)$ & $30.30(22.98 ; 39.56)$ & \\
\hline
\end{tabular}

Table 3. The TGF- $\beta 1$ Levels in Control Group and Two CKD Groups with eGFR $\geq 60 \mathrm{~mL} / \mathrm{min} / 1.73 \mathrm{~m}^{2}$ and eGFR $<60 \mathrm{~mL} / \mathrm{min} / 1.73 \mathrm{~m}{ }^{2}$

\begin{tabular}{|c|c|c|c|c|}
\hline \multirow{2}{*}{ TGF $-\beta \mathbf{1}(\mathbf{n g} / \mathbf{m L})$} & \multirow{2}{*}{$\begin{array}{l}\text { Healthy Control Group }(\mathbf{n}= \\
60)\end{array}$} & \multicolumn{2}{|c|}{ Case Group $(n=152)$} & \multirow{2}{*}{$\mathbf{P}$} \\
\hline & & eGFR $\geq 60 \mathrm{~mL} / \mathrm{min} / 1.73 \mathrm{~m}^{2}$ & $\mathrm{eGFR}<60 \mathrm{~mL} / \mathrm{min} / 1.73 \mathrm{~m}^{2}$ & \\
\hline $\bar{X} \pm \mathbf{S D}$ & $13.45 \pm 7.17$ & $23.86 \pm 8.28$ & $37.88 \pm 10.29$ & \multirow{2}{*}{$\begin{array}{c}\mathrm{P}_{1}<0.001 ; \mathrm{P}_{2}<0.001 ; \mathrm{P}_{3}< \\
0.001\end{array}$} \\
\hline Median (25th; 75th) & $12.44(8.28 ; 17.59)$ & $22.08(20.06 ; 27.79)$ & $36.13(29.50 ; 45.89)$ & \\
\hline
\end{tabular}

${ }^{a} \mathrm{P}_{1}$, control group vs CKD group eGFR $\geq 60 \mathrm{~mL} / \mathrm{min} / 1.73 \mathrm{~m}^{2} ; \mathrm{P}_{2}$, control group vs CKD group eGFR $<60 \mathrm{~mL} / \mathrm{min} / 1.73 \mathrm{~m}{ }^{2} ; \mathrm{P}_{3}, \mathrm{CKD}$ group eGFR $\geq 60 \mathrm{~mL} / \mathrm{min} / 1.73 \mathrm{~m}{ }^{2}$ vs CKD group eGFR $<60 \mathrm{ml} / \mathrm{min} / 1.73 \mathrm{~m}^{2}$.

DM and HTN were excluded. With glomerulonephritis, the renal injuries often occurred with primary renal diseases due to some inflammation agents and the progression of the autoinflammation, so that inflammation were considered to be the main cause of CKD (16). Many inflammation cytokines, such as TGF- $\beta 1$, had a motivating role in the progression of the disease. The TGF- $\beta 1$ increase is associated with the increase of indoxyl sulfate in CKD patients, which is derived from protein in food. Some of the tryptophan from dietary protein is converted to indole by the tryptophanase of intestinal bacteria such as E. Coli indole, which is absorbed into the bloodstream from the intes- 
Van Nguyen T et al.

\begin{tabular}{|c|c|c|c|c|c|c|c|}
\hline \multirow{2}{*}{ TGF- $\beta \mathbf{1}(\mathbf{n g} / \mathbf{m L})$} & \multirow{2}{*}{$\begin{array}{l}\text { Control Group; } \\
\quad \mathbf{n}=\mathbf{6 0}\end{array}$} & \multicolumn{5}{|c|}{ CKD Stage } & \multirow{2}{*}{$\mathbf{P}$} \\
\hline & & Stage $1 ; n=30$ & Stage $2 ; \mathbf{n}=\mathbf{3 0}$ & Stage $3 ; \mathbf{n}=\mathbf{3 0}$ & Stage $4 ; n=31$ & Stage $5 ; \mathbf{n}=\mathbf{3 1}$ & \\
\hline $\bar{X} \pm \mathbf{S D}$ & $13.45 \pm 7.17$ & $22.07 \pm 8.59$ & $25.65 \pm 7.69$ & $35.17 \pm 11.41$ & $37.87 \pm 9.20$ & $40.52 \pm 9.80$ & \multirow{2}{*}{$\mathrm{P}_{\text {all }}<0.001$} \\
\hline $\begin{array}{l}\text { Trung vị (25th; } \\
\text { 75th) }\end{array}$ & $12.44(8.28 ; 17.59)$ & $21.31(13.92 ; 28.13)$ & $\begin{array}{l}23.10(21.67 \\
27.44)\end{array}$ & $\begin{array}{l}32.69(25.57 \\
47.53)\end{array}$ & $\begin{array}{l}36.15(32.18 ; \\
40.16)\end{array}$ & $\begin{array}{l}38.26(34.33 \\
47.21)\end{array}$ & \\
\hline
\end{tabular}

${ }^{a} \mathrm{P}_{\text {all }}$, compare within 6 groups healthy control group and 5 CKD stage groups.

\begin{tabular}{lcccccc}
\hline \multicolumn{1}{l}{ Table 5. The Correlation Between TGF- $\beta$ L Levels and Some Other Characteristics } & & & & \\
\hline Variables & Urea & Creatinine & eGFR & hsCRP & RBC & Hct \\
\hline r & 0.49 & 0.42 & -0.59 & 0.54 & -0.45 & -0.50 \\
PValue & $<0.001$ & $<0.001$ & $<0.001$ & $<0.001$ & $<0.001$ & $<0.001$ \\
\hline
\end{tabular}

tine and is converted to indoxyl sulfate in the liver. Indoxyl sulfate is normally excreted in the urine. In patients with CKD with eGFR $<60 \mathrm{~mL} / \mathrm{min} / 1.73 \mathrm{~m}^{2}$ serum, indoxyl sulfate increases due to decreased clearance. Research by Takashi Minyazaki et al. demonstrated that indoxyl sulfate increases the synthesis of TGF- $\beta 1$ of renal tubular cells, while indoxyl sulfate promotes the penetration of mononuclear leukocytes to the kidney and enhances synthesis into TGF- $\beta 1$ (17). The third mechanism is an increase in LDL-cholesterol in CKD patients. Increased LDLcholesterol and oxidative LDL induce the release of TGF$\beta 1$ from monocytes and macrophages. The fourth mechanism is the low-grade chronic inflammation that occurs in the early stages of CKD, which increases synthesis and releases TGF- $\beta 1$.

Our results showed the TGF- $\beta 1$ level of CKD patients in Vietnam, which is a developing country with an increasing trending of CKD. Some studies demonstrated that TGF- $\beta 1$ level was different in different races, and it did not depend on age and gender $(18,19)$. Meanwhile, other studies investigated the CKD caused by HTN and DM. Our research focused on the CKD caused by glomerulonephritis. The main damages caused by glomerulonephritis were inflammation and fibrinoids, and the TGF- $\beta 1$ levels were high, equal to the renal failure status.

The first limitation of this study was the cross-sectional study. The TGF- $\beta 1$ level was not followed along with the progression of the disease. The second limitation was although this study had evaluated the TGF- $\beta$ levels, it did not show the role of TGF- $\beta 1$ in kidney damage and its relationship with other inflammatory cytokines and complement.

In conclusion, our findings showed a high level of the TGF- $\beta 1$ in CKD patients compared to healthy individuals, and it appeared and increased from the earliest stage of the disease.

\section{Footnotes}

Authors' Contribution: All authors made substantial contributions to conception and design, acquisition of data, or analysis and interpretation of data; took part in drafting the article or revising it critically for important intellectual content; gave final approval of the version to be published, and agree to be accountable for all aspects of the work.

Conflict of Interests: The authors reported no conflicts of interest in this work.

Funding/Support: The author (s) received no financial support for the research, authorship, and/or publication of this article.

\section{References}

1. Schnaper HW, Jandeska S, Runyan CE, Hubchak SC, Basu RK, Curley JF, et al. TGF-beta signal transduction in chronic kidney disease. Front Biosci. 2009;14:2448-65. doi: 10.2741/3389. [PubMed: 19273211]. [PubMed Central: PMC4367189].

2. Frangogiannis N. Transforming growth factor-beta in tissue fibrosis.J Exp Med. 2020;217(3). e20190103. doi:10.1084/jem.20190103. [PubMed: 32997468]. [PubMed Central: PMC7062524].

3. Sheppard D. Epithelial-mesenchymal interactions in fibrosis and repair. Transforming growth factor-beta activation by epithelial cells and fibroblasts. Ann Am Thorac Soc. 2015;12 Suppl 1:S21-3. doi: 10.1513/AnnalsATS.201406-245MG. [PubMed: 25830829]. [PubMed Central: PMC4430968].

4. Higgins SP, Tang Y, Higgins CE, Mian B, Zhang W, Czekay RP, et al. TGF-beta1/p53 signaling in renal fibrogenesis. Cell Signal. 2018;43:110. doi: 10.1016/j.cellsig.2017.11.005. [PubMed: 29191563]. [PubMed Central: PMC5860677].

5. Garcia-Sanchez O, Lopez-Hernandez FJ, Lopez-Novoa JM. An integrative view on the role of TGF-beta in the progressive tubular deletion associated with chronic kidney disease. Kidney Int. 2010;77(11):950-5. doi: 10.1038/ki.2010.88. [PubMed: 20336053].

6. Lopez-Hernandez FJ, Lopez-Novoa JM. Role of TGF-beta in chronic kidney disease: an integration of tubular, glomerular and vascular effects. Cell Tissue Res. 2012;347(1):141-54. doi: 10.1007/s00441-011-1275-6. [PubMed: 22105921]. 
7. Chen L, Yang T, Lu DW, Zhao H, Feng YL, Chen H, et al. Central role of dysregulation of TGF- $\beta /$ Smad in CKD progression and potential targets of its treatment. Biomed Pharmacother. 2018;101:670-81. doi: 10.1016/j.biopha.2018.02.090. [PubMed: 29518614].

8. Ruiz-Ortega M, Rayego-Mateos S, Lamas S, Ortiz A, Rodrigues-Diez RR. Targeting the progression of chronic kidney disease. Nat Rev Nephrol. 2020;16(5):269-88. doi: 10.1038/s41581-019-0248-y. [PubMed: 32060481].

9. Meng XM, Nikolic-Paterson DJ, Lan HY. TGF-beta: The master regulator of fibrosis. Nat Rev Nephrol. 2016;12(6):325-38. doi: 10.1038/nrneph.2016.48. [PubMed: 27108839].

10. Mihai S, Codrici E, Popescu ID, Enciu AM, Albulescu L, Necula LG, et al. Inflammation-related mechanisms in chronic kidney disease prediction, progression, and outcome. J Immunol Res. 2018;2018:2180373. doi: 10.1155/2018/2180373. [PubMed: 30271792]. [PubMed Central: PMC6146775].

11. Cottone S, Mule G, Amato F, Riccobene R, Vadala A, Lorito MC, et al. Amplified biochemical activation of endothelial function in hypertension associated with moderate to severe renal failure. J Nephrol. 2002;15(6):643-8. [PubMed:12495277].

12. Junker U, Haufe CC, Nuske K, Rebstock K, Steiner T, Wunderlich H, et al. Elevated plasma TGF-beta1 in renal diseases: Cause or consequence? Cytokine. 2000;12(7):1084-91. doi: 10.1006/cyto.1999.0645. [PubMed: 10880255].

13. Cottone S, Mule G, Guarneri M, Palermo A, Lorito MC, Riccobene R, et al. Endothelin-1 and F2-isoprostane relate to and predict re- nal dysfunction in hypertensive patients. Nephrol Dial Transplant. 2009;24(2):497-503. doi: 10.1093/ndt/gfn489. [PubMed: 18772174].

14. Gupta J, Mitra N, Kanetsky PA, Devaney J, Wing MR, Reilly M, et al. Association between albuminuria, kidney function, and inflammatory biomarker profile in CKD in CRIC. Clin JAm Soc Nephrol.2012;7(12):193846. doi: 10.2215/CJN.03500412. [PubMed: 23024164]. [PubMed Central: PMC3513744].

15. Vianna HR, Soares CM, Silveira KD, Elmiro GS, Mendes PM, de Sousa Tavares M, et al. Cytokines in chronic kidney disease: Potential link of MCP-1 and dyslipidemia in glomerular diseases. Pediatr Nephrol. 2013;28(3):463-9. doi: 10.1007/s00467-012-2363-x. [PubMed: 23161207].

16. Couser WG. Glomerulonephritis. Lancet. 1999;353(9163):1509-15. doi: 10.1016/S0140-6736(98)06195-9. [PubMed: 10232333].

17. Niwa T. Role of indoxyl sulfate in the progression of chronic kidney disease and cardiovascular disease: Experimental and clinical effects of oral sorbent AST-120. Ther Apher Dial. 2011;15(2):120-4. doi: 10.1111/j.1744-9987.2010.00882.x. [PubMed: 21426500].

18. Suthanthiran M, Gerber LM, Schwartz JE, Sharma VK, Medeiros M, Marion R, et al. Circulating transforming growth factor-beta1 levels and the risk for kidney disease in African Americans. Kidney Int. 2009;76(1):72-80. doi: 10.1038/ki.2009.66. [PubMed: 19279557]. [PubMed Central: PMC3883576].

19. August P, Sharma V, Ding R, Schwartz JE, Suthanthiran M. Transforming growth factor beta and excess burden of renal disease. Trans Am Clin Climatol Assoc. 2009;120:61-72. [PubMed: 19768163]. [PubMed Central: PMC2744541]. 